залогодателю на праве собственности на момент заключения настоящего договора». Тотальный залог в этой ситуации сможет снизить вероятность оспаривания залога со стороны недобросовестных должников.

Но у всего есть вторая сторона. Например, можно смоделировать такую ситуацию, в которой контрагентом залогодателя, заложившего все имущество, будет являться обычный гражданин. Допустим, что этот гражданин, в последующем покупатель, захотел приобрести автомобиль дорогостоящей марки. Компания, реализующая продажу автомобилей, заложила все свое имущество какому-либо банку, при этом внесла информацию в реестр залогов. Из всего вышеперечисленного получается, что покупатель, приходя за покупкой, приобретает автомобиль, обремененный залогом. В такой ситуации, если компания не сможет выполнить свои обязательства перед кредитором, банк, имея всю информацию о покупках авто, вполне может обратиться к покупателям с взысканием. Это еще один существенный недостаток тотального залога. Срабатывает эффект залога против третьих лиц, то есть публичности залога, он не ограничен рядом каких-либо определенных категорий которые должны были быть ограничены, например, как в приведенном мною случае с покупателем. Следует отметить, что во многих международных практиках помимо граждан-потребителей существуют и другие ограничения тотального залога: нанимателей жилья или же граждан-работников при банкротстве компаний.

Подводя итог, хотелось бы подчеркнуть по данному вопросу следующее: новеллы, вошедшие в Гражданский кодекс Российской Федерации, а именно конструкция тотального залога, имеет не только плюсы, но и минусы. Как уже было сказано, удобство залога в том, что кредитор может получить удовлетворение за счет любого имущества, находящегося у должника на момент обращения взыскания, тем самым кредитор снижает риски оспаривания залога со стороны недобросовестных должников. Тем не менее, у новшества есть некоторые недостатки. Законодатель должен скорректировать норму, а именно исключить такой принцип, как следование залога за вещью, в отношении некоторых категорий лиц, а именно гражданпотребителей, заключающих сделки с залогодателями. Особое внимание следует уделить формулировкам, в частности: «залог всего имущества». В данном случае возникает вопрос, входит ли недвижимое имущество в «залог всего имущества», а также и иные объекты, которые требуют обязательной идентификации, например, залог долей в обществе с ограниченной ответственностью или же залог исключительных прав.

$$
* * *
$$

1. "Гражданский кодекс Российской Федерации (часть первая)" от 30.11.1994 N 51-Ф3 (ред. от 29.12.2017).

2. Комментарии к статье 339 Гражданского Кодекса Российской Федерации.

\title{
Карташов И.И., Городилина В.В. \\ К вопросу о соотношении понятий «правосудие» и «судебный контроль» В уголовном судопроизводстве
}

Российский государственный университет правосудия (Россия, Воронеж)

doi:10.18411/spc-20-01-2018-04

idsp: 000001:spc-20-01-2018-04

Аннотация

В статье рассматриваются теоретические вопросы сущности и содержания деятельности суда по осуществлению правосудия и судебному контролю в рамках производства по уголовному делу. Делается вывод о наличии специфических 
признаков, характеризующих контрольную деятельность суда, которые позволяют обособить данную функцию от функции осуществления правосудия.

Ключевые слова: суд, правосудие, судебный контроль, права и свободы граждан, уголовное судопроизводство.

\section{Annotation}

The article deals with theoretical questions of the substance and content of the Court's activities in the administration of justice and judicial control in criminal proceedings. It is concluded that there are specific features characterizing the court's monitoring activities, which make it possible to separate this function from the function of justice.

Key words: The court, Justice, judicial control, citizens ' rights and freedoms, and criminal proceedings.

Судебный контроль представляет собой специфический вид деятельности суда, являющийся элементом механизма обеспечения конституционных прав и свобод граждан, вовлеченных в процесс производства по уголовному делу. Понятие и правовая природа рассматриваемого направления судебной деятельности являются предметом оживленных научных дискуссий с момента принятия УПК РФ, который обозначил его как самостоятельную функцию суда. Это проявляется не только в наличии особых производств, имеющих специфическую материально-правовую базу, но и в имплементации новых процессуальных форм судебной деятельности в рамках общего производства по уголовному делу.

Наиболее значимым применительно к проблеме определения сущности судебного контроля является вопрос о его соотношении с понятием «правосудие». При отсутствии легальной дефиниции споры о содержании судебной деятельности в рамках осуществления правосудия имеют масштабный характер. Одни ученые-процессуалисты не усматривают различий между правосудием и судебной деятельностью[1, с. 156], другие рассматривают их как родовое и видовое понятия[2, с. 17-18], третьи полагают, что процессуальная деятельность суда — это отправление правосудия, а все иные полномочия носят «обеспечительно-распорядительный и опосредованноподчиненных правосудию характер» [3, с. 97]. Применительно к уголовному судопроизводству часть специалистов считает, что суд выполняет единственную функцию осуществления правосудия как в досудебных, так и в судебных стадиях, в одном случае, разрешая возникший уголовно-правовой конфликт, в других - выполняя правообеспечительную и правовосстановительную функции как субъект специального контроля[4, с. 143]. Мы позволим себе усомниться в безоговорочности приведенной позиции. Представляется, что правосудие как разрешение уголовного дела по существу, т.е. реализация судом полномочий, закрепленных в ч. 1 ст. 29 УПК РФ, существенно отличается от судебного контроля по предмету и цели соответствующей деятельности, а также стадиям производства по уголовному делу, в которых реализуются полномочия суда, предусмотренные ч. 2 ст. 29 УПК РФ. Поясним приведенный тезис. Если предметом правосудия является уголовно-правовой конфликт, подлежащий рассмотрению и разрешению судом, то предметом контрольной деятельности - затрагивающие конституционные права и свободы граждан действия и решения должностного лица, ведущего производство по уголовному делу, которые тем или иным образом сопряжены с применением мер государственного принуждения. В этой связи представляется уместным заметить, что утверждения о том, что отождествление правосудия с судебным контролем ставит под угрозу действие основного принципа судопроизводства - состязательности, в рамках которой суд не может быть вовлечен в реализацию функции уголовного преследования[5, с. 30-32], являются небезосновательными. 
Кроме того, как уже было отмечено, деятельность суда в рамках судебного контроля имеет своей целью защиту и (или) восстановление нарушенных прав и свобод участников уголовного процесса, которое осуществляется вне судебных стадий производства по уголовному делу, в то время как основной целью правосудия является назначение виновным справедливого наказания либо освобождение невиновных от наказания, а также реабилитация каждого, кто необоснованно подвергся уголовному преследованию (ч. 2 ст. 6 УПК РФ), что осуществляется исключительно в рамках судебного разбирательства и последующих судебных стадий производства по уголовному делу.

На наш взгляд, не вполне справедливы рассуждения о тождестве понятий правосудие и судебный контроль, основанные на том факте, что оба вида деятельности производятся в рамках судебного заседания, проводимого по правилам, формирующим общие условия судебной деятельности (подсудность, гласность, непосредственность устность, неизменность состава суда и т.д.) [6, с. 124]. В данном случае происходит явное смещение акцентов с сущности и содержания соответствующей деятельности на ее форму. Именно такой подход, на наш взгляд, прослеживается при конструировании лексического инструментария законодателя, который определяет судебное заседание как процессуальную форму деятельности по осуществлению правосудия (п. 50 ст. 5 УПК РФ). Все судебные решения, связанные с реализацией полномочий, предусмотренных ч. 2 ст. 29 УПК РФ, «принимаются в специально проводимых судебных заседаниях с соблюдением общих условий судебного разбирательства... кроме того, эти решения суда, так же, как и приговор, согласно действующему законодательству, могут быть обжалованы участниками процесса» [7, с. 491].

Думается, что судебный контроль может быть обозначен как самостоятельное направление деятельности суда, которое вторично по отношению к его основной функции - осуществления правосудия, ибо не затрагивает основного вопроса судопроизводства - разрешения по существу возникшего уголовно-правового конфликта. Как отмечает Л.А. Воскобитова, целью реализации полномочий в рамках судебного контроля является «сдерживание органов государства, ведущих процесс, для защиты конституционных прав и свобод граждан и обеспечения верховенства права» $[8$, c. 175$]$.

В отличие от решения вопроса о виновности лица в совершении преступления, контрольные полномочия суда по своему содержанию не являются однородными и не реализуются вне инициативы участников судопроизводства. Так, судебный контроль может быть предварительным, если суд рассматривает ходатайство должностного лица, ведущего предварительное расследование, о производстве следственного действия либо применении меры принуждения (продлении ее срока), связанных с возможным ограничением конституционных прав и свобод кого-либо из участников уголовного процесса, а также иных лиц, вовлеченных в его орбиту в связи с производством по уголовному делу (ч. 2 ст. 29 УПК РФ). В этом случае полномочия суда носят исключительный характер и правообеспечительную направленность. Иную форму имеет последующий судебный контроль, осуществляемый по инициативе субъекта, обратившегося с жалобой на нарушение его конституционных прав либо ограничение права на доступ к правосудию (ч. 3 ст. 29 УПК РФ). В данном случае речь идет о правовосстановительной деятельности суда, поскольку предметом возникшего спора являются уже совершенные следователем, дознавателем действия (бездействие) либо принятые решения.

Таким образом, можно констатировать, что судебный контроль в уголовном судопроизводстве представляет собой многофункциональную деятельность суда в стадиях возбуждения уголовного дела и предварительного расследования, осуществляемую в установленной законом процессуальной форме, направленную на 
судебную защиту и восстановление конституционных прав и свобод участников уголовного процесса, а также обеспечения гражданам доступа к правосудию.

$$
* * *
$$

1. Махов Н.Н. Правосудие в России: проблемы и решения. Красноярск, 2010. С. 156 - 170.

2. Алехин К.Е. Судоустройство и судопроизводство в РФ: Учебник для вузов. Калининград, 2011. $617 \mathrm{c}$.

3. Актуальные проблемы деятельности судов общей юрисдикции Российской Федерации: Учебник / под ред. В.М. Бозрова. М.: Юстиция, 2017. 568c.

4. Таричко И.Ю. Функция судебного контроля в Российском уголовном процессе: Дис. ... канд. юрид. наук. Омск, 2004. 226с.

5. Ковтун Н.Н. Судебный контроль в уголовном судопроизводстве России. Н. Новгород: Нижегородская правовая академия, 2002. 520с.

6. Ерохина О.С. Сущность участия следователя в судебном заседании в ходе досудебного производства по уголовному делу // Евразийский юридический журнал. 2011. № 11 (42). С. 123 127.

7. Судебная власть и правосудие в Российской Федерации: Курс лекций / Под ред. В.В. Ершова. М.: РАП, 2011. 904c.

8. Воскобитова Л.А. Механизм реализации судебной власти посредством уголовного судопроизводства: Дис. ... д-ра юрид. наук. М., 2004. 460с.

\section{Попов А.В. \\ Актуальные вопросы организации оперативно-розыскной деятельности по раскрытию убийств, совершаемых по найму}

Академия управления МВД России

(Россия, Москва)

doi:10.18411/spc-20-01-2018-05

idsp: 000001:spc-20-01-2018-05

Заказные убийства, как правило, совершаются в условиях неочевидности, в результате чего в большинстве случаев достаточно трудно выявить признаки, на основании которых можно сделать вывод об убийстве совершённом по найму.

Данный вид преступлений имеет определённую схему подготовки и совершения: «ПОТЕРПЕВШИЙ - НАНИМАТЕЛЬ - ПОСОБНИК - ПОСРЕДНИК НАЕМНИК (ИСПОЛНИТЕЛЬ)». Данные обстоятельства оказывают влияние на методы и формы документирования.

По делам об убийствах, в отношении которых выдвигается версия о их совершении по найму, первоначальный этап раскрытия должен привести к основаниям выдвижения такой версии. Поэтому, на первоначальном этапе раскрытия убийства как совершенного по найму, можно утверждать, только тогда, когда для этого имеются необходимые основания.

Традиционным направлением раскрытия заказного, как и иного, убийства, является работа «от преступления - к лицу». Она организуется в соответствии с информацией и данными, полученными на месте происшествия. Анализ материальных следов (огнестрельное и холодное оружие, боеприпасы, следы крови, пули, извлеченные из трупа, гильзы, пыжи, окурки и т. п.) приводит к выдвижению оперативно-розыскных версий. Поэтому основное значение имеет своевременное обнаружение и изъятие на месте происшествия следов рук и других криминалистически значимых следов, вещественных доказательств, оставленных преступниками и их сообщниками. В сочетании с данными, полученными оперативнорозыскным путем, собранные материалы могут способствовать обеспечению наступательности в поиске преступников. Например, по изъятому с места происшествия оружию, помимо следственных действий, проводится ряд оперативнорозыскных мероприятий:

- проверка по соответствующим учетам; 